\title{
Büyüsü Bozulan Avm'yi Büyülemek: \\ Kent Simülasyonunda Yaşam Tarzının Tüketimi
}

\section{Enchanting a Disenchanted Mall: Life Style Consumption in Urban Simulation}

Diretgen Ozan ERCANSUNGUR*

(D) 0000-0002-4915-9210

\author{
Ahmet TALIMCILER $^{* *}$ \\ 0000-0002-7193-9475
}

MAKALE BİLGISİ

Başvuru: 29. 03. 2021

Düzeltme Talebi: 26. 04. 2021

Son Düzeltme: 18. 07. 2021

Kabul: 29. 07. 2021

Online Yayım: 15. 08. 2021

\section{Anahtar Kelimeler:}

Tüketim,

Yaşam tarzı

Alışveriş merkezi

Yaşam merkezi

Simülasyon

\section{ÖZ}

Modern dönemle birlikte kitlesel bir fenomene dönüşen tüketim, yalnızca ihtiyaçların karşılanması değil, arzuların tatmini ile ilişkili bir hal almıștır. Günümüzde bu arzuların hızı, yoğunluğu ve kapsamı önemli boyutlara ulaşmıştır. Tüketim artık kültürel pratiklerden sanatsal faaliyetlere uzanan, toplumsal kimlik ile yakından ilişkili bir deneyimin alanı haline gelmektedir. Bu değişim kendisini alışveriş merkezlerinin yapısında da göstermektedir. Çalıșmanın öncelikli hareket noktası, George Ritzer'in öne sürdüğü yeni tüketim araçlarının akılcılaşması ve büyülemesi arasındaki denge fikridir. Bu dengenin bozulduğunu iddia ettiğimiz, giderek akılcılaşan alışveriş merkezleri, kültürel pratiklerini, sınıfsallığını, kimliğini ve kentliliğini tüketerek deneyimleme amacındaki tüketicilerin beklentilerine cevap vermemektedir. Merkezine yaşamı alan "yaşam merkezleri" -ya da yeni alışveriş merkezleri- bu beklentilerin etkisiyle yeni bir form olarak ortaya çıkmıștır. Değișen kültürel pratiklerin, sınıfsal ayrımın ve "yeniden büyüleme" olarak yașam tarzının tüketiminin yeni alanı olan bu merkezler artık kentin bir parçasından öte, kentin ta kendisidir. Bir kent simülasyonu olarak öne çlkan bu merkezlerde kentliliğin simülakrı üretilmekte, tüm bu büyülü dünya aynı zamanda akılcı ve pratik bir paketle tüketicilerine sunulmaktadır. Bu çalıșmada yaşam merkezleri, giderek akılcılaşan alışveriș merkezlerinin bu krizi aşmak adına ulaştıkları yeni bir form olduğu iddiası ile ele alınmaktadır. Çalışmanın amacı bu iddiayı teorik bir tartışmaya açmaktır; özellikle Pierre Bourdieu ve Jean Baudrillard'ın görüşleri ile yürütülecek bu teorik tartışma ile kültür ve yaşam tarzının konu edildiği, dönüşmekte olan tüketim pratikleri ve alışveriş merkezlerindeki görüntülerinin değerlendirilmesi amaçlanmaktadır.

\section{AB S T RACT}

Consumption has been transformed into a massive phenomenon in the modern era, and it is not just about fulfilling needs; it is related to satisfying one's desires. The speed, density, and extent of these desires reached a considerable size in our current world. Consumption now is a field of experience closely related to cultural practices, artistic activities, and social identities. It is possible to follow this transformation in the structure of shopping malls. The study's starting point is George Ritzer's idea of the balance between rationalization and enchantment of new means of consumption. Increasingly rationalized shopping malls, which we claim lost the balance, can not answer consumers' expectations whose purpose is to experience their cultural practices, class, identity, and urbanity through consumption. "Lifestyle centers" -or new shopping malls-, which center life is a new form that emerged from those expectations. These lifestyle centers are not just part of urban space. They are the urban itself and the field of changing cultural practises, class distinction, and consumption of lifestyles as "re-enchantment." These lifestyles operate within simulation produce situated in urban areas, and all this enchanted world appears in a rational and practical package for its consumers. In this study, lifestyle centers are considered a new form of shopping malls to overcome rationalization. This study aims to bring this claim up for a theoretical discussion; in this way, we aim to evaluate the transforming consumption practices closely related to culture and lifestyle and its reflections on shopping malls, especially along with the thoughts of Pierre Bourdieu and Jean Baudrillard.

\footnotetext{
* Yazar İletişim/ Corresponding Author: Diretgen Ozan Ercansungur (Arş. Gör.), Manisa Celal Bayar Üniversitesi, Fen Edebiyat Fakültesi, Sosyoloji Bölümü, Manisa, Türkiye凶 ozan.ercansungur@cbu.edu.tr

** Ahmet Talimciler (Prof. Dr.), İzmir Bakırçay Üniversitesi, Fen Edebiyat Fakültesi, Sosyoloji Bölümü, İzmir, Türkiye 凶ahmet.talimciler@bakircay.edu.tr

Kaynak Gösterimi/ Citing This Article: Ercansungur, D. O. ve Talimciler, A. (2021). Büyüsü bozulan Avm’yi büyülemek: Kent simülasyonunda yaşam tarzının tüketimi. Sosyolojik Bağlam Dergisi, 2 (2), 94-106. Doi:10.52108/2757-5942.2.2.6
} 


\section{Giriș}

Tüketim, yalnızca hayatta kalmanın devamı için gerçekleştirilen bir eylem olarak öne çıkmaz. Kavram, toplumsal bir olgu olması yönüyle de yeni bir kavram değildir. Ne var ki bu olgu, sanayi devrimini takiben yaşanan bir dizi değişme ile toplumsal önemi artan bir olgu haline gelmiştir. Özellikle 20. yüzyllla beraber tüketim, toplum yaşamında merkezi bir önem taşıyan, birçok düşünüre göre ise makro düzeyde belirleyici bir olgu haline gelmiştir. Bant üretimin gelişmesi ile ihtiyaçların üretimi pazar için üretime dönüşürken, tüketim de giderek "arzu" için gerçekleşmeye başlayacaktır. Bu arzular ise kaçınılmaz olarak kültürel dünyamız ile ilişkili olarak ele alınacaktır. Neyi arzuladığımız kim olduğumuza, bu arzuları tatmin edip edemediğimiz ise toplumsal statümüze işaret eden göstergelere dönüșecektir.

$\mathrm{Bu}$ göstergelerin tüketimi sanayileşmenin doğasına uygun bir şekilde akılcılaştırılmıştır. George Ritzer tüketim araçlarının tüm bu akılcılaştırma sürecini verimlilik, hesaplanabilirlik, öngörülebilirlik ve insansız teknolojiler gibi temalar altında incelemeye tabi tutar. Büyüsü Bozulmuş Dünyayı Büyülemek: Tüketim Katedrallerindeki Süreklilik ve Değişim (1999) isimli çalışması ile tüketime özgü önemli bir analiz geliştirir; tüketim tüm bu akılcılaştırılmanın yanında tüketici için büyüleyici bir karaktere de sahip olmalıdır. Tüketimin bu büyüleyici karakteri, kapitalizmin akılcı unsurları ile hassas bir dengede durur; çeşitli fantezilerle insanları tüketime çekmek adına bu fanteziler akılcılaștırılabilir fakat bu akılcılaștırma fanteziyi bir demir kafese de döndürme riskini beraberinde taşır. Alışveriş merkezlerinin alametifarikası da buradadır; bu büyülü ortamlar, tüketicileri rüya benzeri bir duruma çekip tüketimi denetlemeye uygun ortamlar sunar. Ne var ki uzun vadede, çok sayıda tüketiciye hizmet edip denetleyebilmek bu merkezlerin kaçınılmaz olarak akılcılaşmasını zorunlu kılar ve bu akılcılaşma büyünün bozulmasına, tüketicileri çekme kapasitelerinde ise bir düşüşe yol açar. Bu yönüyle alışveriş merkezleri (birçok diğer tüketim aracı gibi) sürekli olarak çözüm bekleyen bir tür ikilemle karşı karşıyadırlar (Ritzer, 2019: 123). Söz konusu yalnızca kapitalist akılcılaşmanın alışveriş merkezleri üzerindeki etkilerinden ibaret de değildir. Tüketim, tüm yaşam alanlarına sıçrayan, anlam dünyamıza etki eden, her geçen gün kapsamı genişleyen bir olgu olarak toplumsal ağırlığını arttırmaktadır. Tüketim pratikleri de tüketici beklentileri de her geçen gün dönüşmektedir; kültürel pratiklerini, sınıfsallığını, kimliğini ve kentliliğini tüketerek deneyimleme amacında büyük bir kitle söz konusudur. Şüphesiz bu kitlenin beklentileri, alışveriş merkezlerinin izleyeceği yolun da yönünü belirleyecektir.

Alışveriş merkezlerinin karşı karşıya olduğu ikilemin ve dönüșen tüketici beklentilerinin, bugün yaşam merkezleri olarak ismi geçen merkezlerin ortaya çıkmasında ilişkisel bir süreci temsil ettiği görüșündeyiz. Söz konusu yaşam merkezleri gerek mimari tercihleri gerek düzenli uyguladıkları etkinlikler gerekse hedefledikleri tüketici pratikleri nedeniyle diğer alışveriş merkezlerinden ayrı ele alınmalıdırlar. Bu düşünceden hareketle çalışma yaşam merkezlerinin ayrı ele alınması gereken bir üst-form olduğu iddiasındadır; akılcılaşan dünyayı büyüleyen alışveriş merkezlerinin kendileri de akılcılaştıkça, büyülemenin yeni formu olarak yaşam merkezlerine dönüşmektedirler. $\mathrm{Bu}$ merkezlerde büyülemenin yeni yolları, mevcut akılcılaşmanın dışında yeni yöntemler aracılığıyla hayata geçmektedir. Kültürel boyut bu yeni yöntemlere büyük ölçüde kaynaklık etmekte, tüketim de giderek bir yaşam tarzının tüketimine dönüşmektedir. $\mathrm{Bu}$ yeni formun analizinin alışveriş merkezlerinin dönüşümüne ışı tutması, kültür ve yaşam tarzı konusunda günümüz insanının yaklaşımına dair önemli ipuçları sunması beklenmektedir. Gündelik tüketimin mekânı olma amacı bu merkezleri kentin bir parçasından kentin simülasyonuna, yaşamın merkezine dönüştürmekte, tüketici ise bu simülasyonda kentli simülakrını yeniden üretmektedir. Bu çalışmanın amacı çeşitli yaşam merkezlerinin uygulamalarından örnekler vermekle birlikte bu sürecin kuramsal bir analize tabii tutulması, teorik bir tartışma yürütülmesidir. 
Bugün sosyal bilimler için başlı başına bir çalışma alanı oluşturan tüketim, özellikle 1960’lı yılların ardından boyut değiştirmiş ve günümüzdeki önemine ulaşmıştır. Bununla birlikte üretimin bir ideal olarak yüceltildiği modern dönemin en akılcı günlerinde dahi toplumsal ve kültürel bir olgu olarak varlığını fazlasıyla hissettirmektedir. Max Weber sosyolojisinde bunu gözlemlemek mümkündür; Weber'in tüketim araçları "akılcılaştırılmış" yapılar olarak kapitalist akılcılığın bir parçasını oluşturur; tüketim, statüye işaret edecek olan piyasa konumu ile yakından ilişkili toplumsal ve kültürel bir eylem olarak öne çıkar (Batı, 2009: 24-25). Tüketim dönemin karakteristiğine paralel bir şekilde ele alınmıştır, bu karakteristik ise düşünürün "demir kafes" olarak tanımladığı kapitalizmin biçimsel akılcılığıdır. Bu kaçınılmaz olarak evrensel bir düzenleme ile yönlendirilen, büyüsü bozulmuş bir dünya görüntüsü taşır, Weber'in ön görüsü de bu konuda karamsardır; “[...] önümüzde rengârenk çiçekler değil buz gibi bir karanlık ve sert kutup gecesi var." (Akt. Ritzer, 2019: 104-105). Georg Simmel ise bu renksizliği artan iş bölümünün tek yönlü talepleri ile bireyin kişiliğinin geriye itilmesinin bir sonucu olarak görür. Bu muazzam akılcı güçler organizasyonunun bir dişlisinden ibaret birey artık ihmal edilebilir bir niceliğe indirgenmiştir. Bu sebeple kişiliğinin çekirdeğini koruyabilmek, sahip olduğu eşsizliği ve tikelliği öne çıkarmak adına elinden geleni ardına koymayacaktır. Tüketim kaçınılmaz olarak metropol insanının çaresiz arayışına araç olacaktır (Simmel, 2021: 224-225). Bu açıdan bakıldığında Thorstein Veblen'in aylak sınıfı ve gösteriş̧̧i tüketimi, benzer bir çaresizliğin sonucu olarak ele alınabilir. Kişinin statü ve prestijini göstermek amacı ile gerçekleştirdiği lüks ve pahalı tüketimler olarak gösterişçi tüketim, çalışmanın yerildiği aylak sınıfa özgü bir eylem şeklidir (Ritzer ve Stepnisky, 2014: 195). Veblen sosyolojisinde statü ve prestijin gösterişine konu olan tüketim, yirminci yüzyılın ikinci yarısıyla birlikte toplumsal bir ideale dönüşmeye başlamaktadır. Jean Baudrillard'ın tüketim toplumu ile vurgulamak istediği en önemli nokta da budur, tüketim yalnızca önemli bir olgu olarak değil, tüm toplumun mantığını niteleyen bir kavram olarak öne çıkmaktadır. Burada söz konusu olan hâkim değer yasasında gözlemlenen değişimdir. Sanayileşmiş kapitalist toplumlarda akılcı düşünce yapısına uygun olarak belirlenen kullanım değeri ve değişim değeri mantığı belirleyiciliğinde takip eden süreç artık son bulmuş, tüketim iliş̧kilerinin öne çıktığı, anlam üretimi ve bu anlamın doğasına etki eden göstergelerin hâkim değer yasasında belirleyici olduğu bir döneme girilmiştir. Söz konusu olan sanat eserlerine özgü bir değer yasası ile benzerlik gösterir; özgün bir değere sahip olan sanat eserinin bedeli bir anlamda eserin taşıdığı toplumsal anlam ve işlev açısından belirlenir. Bu noktada kapitalizm bu türden bir değer yasasını tüm alanlara egemen kılmış ve bir sonraki aşama olan tüketim toplumu aşamasına geçmiştir (Adanır, 2016: 45-46).

Baudrillard'ın öne sürdüğü bu aşama ile birlikte tüketim, toplumsal yaşantının her alanında izlerini takip etmenin mümkün olduğu bir sürece yön verir. Söz konusu olan yalnızca mağaza ve alışveriş merkezleri değil, temalı parklar, kumarhaneler ve gemi şirketleri gibi, aynı zamanda giderek tüketim araçlarına daha çok benzemeye başlayan stadyumlar, üniversiteler, hastaneler ve müzelerdir (Ritzer, 2019: 30). Kentleşme buradaki diğer önemli boyuttur. İlk örneklerinden bugüne ticari ilişkilerin çevresinde gelişen kentler, zamanla belirleyeni olan ticari faaliyetleri de şekillendirmiș, özellikle tüketim kültürünün hızlı yükselişi ile birlikte tüketimin yeni arenası haline gelmiştir. Özetle artık her yer giderek alışveriş merkezlerine benzemekte, bugün gelinen noktada ise alışveriş merkezleri yaşamın merkezi olma iddiasındadırlar.

Dönüşen tüketim pratikleri ve alışveriş merkezlerindeki görüntülerini takip etmek amacında olduğumuz bu çalışmanın öncelikli hareket noktası, George Ritzer'in ünlü eseri “Büyüsü Bozulmuş Dünyayı Büyülemek"'de öne çıkardığı yeni tüketim araçlarının akılcılaşması ve büyülemesi arasındaki denge fikridir. Tüketim hala Weber'in öne sürdüğü şekliyle akılcı bir değer dizisi olarak ya da Simmel'in ifadesiyle metropol insanının tikelliğini sergilediği bir araç olarak ele alınabilir, ya da Veblen'i takip edersek "gösteriş" tüketimin temel mantığında hala yer almaktadır fakat günümüzde önemi ve ağırlığı fazlasıyla artmakta olan bu sürecin artık kapsamı da genişlemiştir. Artan bu önem ve ağırlığı ile tüketim artık basit işlev sınırını aşmış, giderek daha büyülü olması 
gereken bir deneyime dönüșmektedir. Bunun aksine akılcılaşan tüketimin mantığl, alışveriș merkezlerinin büyüsünün bozulmasıyla sonuçlanmış, dolayısıyla bu merkezler büyülemenin yeni şekillerine sahne olmaktadır. Hem panayırların karnavalesk geleneğini sürdüren hem de kent yaşamının estetikleştirilme sürecinin yansımalarını barındıran alışveriş merkezleri, yalnızca tüketim mekânları değil aynı zamanda sosyalleşme alanları ve kentsel etkinliklerin gerçekleştirildiği merkezlerdir. Bununla birlikte bazı alışveriş merkezleri gerçekleştirdikleri kültürel ve sanatsal etkinliklerle bir yaşam tarzı sunmaları bakımından diğer örneklerinden ayırt edici niteliklere sahip olmaktadır.

Modanın karakteristiğini incelerken Simmel, hızlı değişimlerin, yani bir çırpıda popüler olma ve aynı hızla demodeleşme gibi sürekli takip etmeniz gereken bu önemli farkların, modern zamanları geçmişe klyasla "çok daha tedirgin" bir çağ haline getirdiğini anlatır. Modayı önemli kılan ise yalnızca ne yiyip ne içeceğiniz ya da nerede ne giyeceğiniz ile ilişkili olmamasıdır. Moda; sınıf farklılığına işaret etmekte, sürekli içerik değişimi ile farklı olma ihtiyacını ve benzersiz olma eğilimini tatmin etmektedir. Toplumun üst tabakası ile alt tabakasının modası asla birbirine benzemeyecek, yenisi hazır olur olmaz eskisi de terk edilecektir (Simmel, 2021: 197). Şüphesiz bu temel mantık devam etmektedir. Ne var ki artık kültür, tüketimin alanındadır; dolayısıyla kültürel ayrımın göstergesi de neyi, nasıl tükettiğinize dönüşmektedir. Featherstone, günümüzde meta akışının sürekli değiştiğinden metaya sahip olanların statülerinin de giderek karmaşıklaştığından bahsetmektedir. Seçkinlik arayışından dolayı entelektüeller kültürün demokratikleşmesi doğrultusundaki hamlelere direnerek her zaman kültür alanının özerkliğini artırmaya ve kültürel sermayenin kıt bulunmasını sağlama almaya çalışmaktadırlar (Featherstone, 2013: 45, 160). Söz konusu olan sınıflar arası kültürel bir tahakküm ilişkisinden ibarettir ve bu durum kendisini açıkça yaşam tarzı konusunda göstermektedir.

Fransız düşünür Pierre Bourdieu'nun "ayrım” kavramı ile geliştirdiği yaklaşımı, yaşam tarzları ve sınıflar arası farklılaşma arasındaki ilişkiyi öne çıkarmaktadır. Bourdieu'nün kuramsallaştırmasında sınıflar arası ayrımı yaratan en önemli eşitsizlik üretim aracı beğeni fenomeni ve beğeninin etkisiyle meydana gelen yaşam tarzlarıdır. Bourdieu beğeni fenomenini egemen sınıfın beğeni karakteristiği olan meşru beğeni, orta sınıfların beğeni karakteristiği olan ortalama beğeni ve halk sınıflarına doğru gidildikçe yoğunluğu artış gösteren popüler beğeni olarak üç bölümde inceler (Bourdieu, 2015a: 31-32). Beğeni yargısının farklılaşması düşünürün en temel düşünme araçlarından biri olan habitus ile yakından ilişkilidir. Habitus, eylemin -aynı zamanda onun tarafından yapılandırılan- yapılandırıcısıdır: bireyin doğumundan itibaren önce aile, sonrasında eğitim sisteminin içinde ona verilen ve yaşantısı boyunca gelișen kültür ve davranış kodları olarak düșünülebilecek olan habitus (Bourdieu, 2015a: 105), toplumsal olanın bedende cisimleşmesidir ve bireyin seçimlerini yönlendiren bir yatkınlıklar sistemi olarak çalışır (Bourdieu, 2007: 214). Bireysel anlamda bir işleve sahip olan habitus, sınıfsal anlamda da "sınıf habitusu" halini alır; bir başka deyişle benzer yaşam koşulları benzer beğenileri ve benzer kültürel pratikleri üreterek Bourdieu'cü anlamda toplumsal sinıfları meydana getirir (Swartz, 2015: 215). Beğeni yargısının farklılaşması, dolayısıyla ayrım, sınıf habitusunun bir sonucudur ve bu ayrım sonucunda farklı toplumsal sınıflar arasında kültürel ve fiziksel bir mesafe oluşur. Öyledir ki oluşan bu mesafede farklı toplumsal sınıflara mensup kişilerin birbirleriyle fiziksel olarak karşılaşma olanakları yoktur, karşılaştıklarında da bu rastgele bir karşılaşma olacaktır ve bu karşılaşmanın sonucunda "birbirlerini anlamayacak ve birbirlerinden hoşlanmayacaklardır" (Bourdieu, 2015b: 25).

Bourdieu, toplumsal sınıflar arasındaki ayrımın üretilmesinde sermaye kavramının da belirleyici olduğunu ifade etmektedir. Bu alandaki en önemli sermaye türleri ise, tüm alanların ve toplumsal uzamın da üzerinde yapılandığı ekonomik sermaye ve kültürel sermayedir. Ekonomik sermaye ve kültürel sermaye birbirlerinin karşıtı olarak işlev kazanabildikleri gibi aynı zamanda birbirlerine de dönüșebilirler. Ekonomik sermaye kültürel sermayeye iyi ve kabul görmüş kurumlarda eğitim alma, çeşitli yabancı diller öğrenebilecek kaynaklara sahip olma, kültürel yoğunluğu yüksek objeleri satın alabilme gibi yollarla dönüşebilir ve nihayetinde ekonomik sermayenin en güçlü taşıyıcıları, bir 
anlamda kültürel sermayenin de en güçlü taşıyıcıları olmaya muktedirlerdir. Gerçek anlamda hâkim sınıfların kültürel çözümlenmesinde Bourdieu bu hususu temele alır ve onların "ayrıcalıklı" tüketimi ile halk sınıflarına doğru gidildikçe artan yoğunluktaki "avam" tüketim arasındaki karşıtllıta sınıflar arası ayrımı ve dolayısıyla toplumun yeniden üretimini temellendirir (Bourdieu, 2015a: 262).

Beğeni yargısı temelinde gerçekleşen farklılaşma büyük ölçüde sınıf habitusu ve sermaye ile ilişkilidir. Bourdieu bu ilișkinin bir sonucu olarak ayrımın toplumsal kimlikte somutlaştığını öne sürer. O'na göre toplumsal kimlik farklılıkta tanımlanır ve kendini ortaya koyduğu yer diğerleriyle olan farklılaşmasıdır. Kimliğin farklılaşması kültürel pratiklere gömülmüş vaziyettedir ve burada dikotomik karşlıklarda (alt/üst, yüksek sanat/bayağı sanat, işlev/estetik gibi) kendini dışarı vurarak bu farklılaşmayı tetikler (Bourdieu, 2015a: 256). Toplumsal formlar, giyim kuşam, estetik değerler gibi tüketime içkin ögeler tarafından dönüştürülmektedir. Simmel'in söylediği gibi bu tam manasıyla bir döngüdür; "Alt sınıflar üst sınıfların tarzını kopya etmeye başlar başlamaz, yani üst sınıfların çizdiği sınır çizgisini geçip sınıfın bütünlüğünü bozduğunda, üst sınıflar söz konusu tarzı bırakmakta ve kendilerini kitlelerden farklı kılan yeni bir tarzı kabul etmektedir; böylece oyun yeniden başlar." (Simmel, 2021: 199). Bu yönüyle ayrım, aynı sınıfta olanların idealize edilmesiyle birlikte, diğer tüm grupların dışarıda bırakıldığını da göstermektedir. Söz konusu yaşam tarzı olduğunda bu süreç sürdürülmesi zor bir sürece dönüşmektedir.

Belirli bir yaşam tarzının sürekli sürdürülmesi büyük ölçüde bir zorunluluk halini alır. Hiçbir seçime sahip olmamakla birlikte, seçim yapmak zorunda kalırız. Giddens'ın ifadeleriyle; "Bir hayat tarzı, bir bireyin benimsediği az çok bütünlük içindeki bir pratikler topluluğu olarak tanımlanabilir; bunun nedeni, sadece, bu tür pratiklerin ihtiyaçları karş̧laması değil, aynı zamanda özel bir bireysel-kimlik anlatısına maddi bir biçim kazandırmalarıdır." (Giddens, 2014: 110). Hâkim sınıflardan halk sınıflarına doğru gidildikçe değișen kültürel pratikler, sınıfların kendi pratiklerini yüceltmesi, farklı sınıfların pratiklerini dışlaması ve bir anlamda kendi alanını korumaya yönelik bir pratik geliştirmesi, sınıflar arasındaki ayrımın ve dolayısıyla toplumsal uzamdaki görünümün yeniden üretiminin nedenidir; ayrım budur. Kültürel pratiklerde ve beğenide ortaya çıkan temel farklılaşma hâkim sınıfların zorunluluğa uzak ve keyfi olan (böylece estetiğe yönelik olabilme şansı olan) özgür beğenisi ile halk sınıflarının zorunluluklardan kaynaklanan ve bir noktada bir erdem gibi beğeni halini alan zaruri beğenisi arasındaki uzaklıkta kendini gösterir (Bourdieu, 2015a: 265). Alışveriş merkezleri konusunda -sermaye ve habitus ekseninde yapılanan- toplumsal sınıfların farklılaşmasına bu çerçeveden yaklaşllabilir. Yaşam merkezleri olarak anılagelen yeni alışveriş merkezleri Bourdieu'nün ekonomik ve kültürel sermaye türlerine sahip bireylerine hitap eden, ya da bu sınıfı hedef kitle olarak seçen uygulamalarıyla kültürel ayrımın alanına dönüşmekte ve diğer örneklerinden ayrışmaktadır.

\section{Alışveriş Merkezinden Yaşam Merkezine: Yaşam Tarzının Tüketimi}

Satıcının ihtiyaçları ile alıııın ihtiyaçlarının karşılaştığı yerler, buna ister agora, ister bedesten, ister pazar deyin, her zaman alışverişin sınırlarını aşan toplumsal mekânlar olmuşlardır. Modern alışveriş merkezlerinin ilk örnekleri olarak alınan antik dünyanın pazar yerleri agoralar çoğu zaman eğlence ve politik amaçlarla da kullanılıyor, dönemin teolojik inançları tarafından gözetiliyordu. Kendisi de bir yağ tüccarı olan Platon "tüm kazıklama çabalarının" Zeus tarafından izleniyor olduğunu yazıyordu. Ticaret ve alışveriş, kentleşmeyle paralel bir gelişme seyrediyor, özellikle Ortadoğu'da Petra, Palmyra gibi bizatihi mal değișim noktası olmaları amacıyla görkemli kentler kuruluyordu. İstanbul'un fethini takiben yaşanan mimari atılımın önemli sonuçlarından biri ise bedestenlerdi; her tür kıymetli eşya alışverişine ayrılan bedestenlerin en önemli ayırt edici özellikleri ise üretici, aracı ve tüketiciyi tek bir kapalı mekânda buluşturmasıydı. Rönesans ile şekillenmeye başlayan burjuva ekonomisi, sanayi devrimiyle önemli bir yükselişe geçecek, alışverişin merkezleri de modern döneme özgü paradigmayla yeniden yorumlanacaktı (Çalışlar, 2019: 24-96). Featherstone ayrıca panayırların da modern alışveriş merkezleri açısından önemli etkileri olduğunu eklemektedir. Eskiden karnavalesk geleneğin sürdürüldüğü panayırlar hem yerel 
pazar hem de haz ortamları olarak işlev görmekteydi. Panayırlar sadece metaların mübadele edildiği ortamlar değil, sıra dışı ürünlerin sergilendiği alanlardı. Kent yaşamı gibi panayırlar da çarpıcı manzaralar eşliğinde ilginç ses, hareket, imge, insan ve hayvanların birbirine karıştığı büyülü bir ortam sunuyorlardı. 19. yüzyılın ikinci yarısında gelişen alışveriş merkezleri ise panayırların karnavalesk geleneğinin yeni alanı haline gelmişlerdi (Featherstone, 2013: 54-55).

Modern -günümüzden bakıldığında artık geleneksel- alışveriş merkezleri, tek bir mekân içerisinde geniş bir yelpazede ürün çeşitliliği sunma vaadi ile tüketicilerine hitap etmektedirler. Yıllar geçtikçe büyüyen bu mekânlar, eğlence sektörüne yönelik mağazaların yanında hizmet sektörünün de giderek geliştiği, dolayısıyla mekân dâhilinde gerçekleşen tüketim pratiklerinin doğasının farklılaştığı mekânlar haline geldiler. Bu dönüşüm günümüzde oldukça yaygin bir uygulama halindedir denebilir, küçük alışveriş merkezlerinde dahi fast-food mekânlarından sinema salonlarına kadar çeşitli tüketim aktivitelerine imkân veren yapılanmalar gözlenmektedir (Bloch vd., 1994: 24). Burada giderek akılcılaştırılan bir sistem söz konusudur, gitgide daha fazla tüketiciyi kendine çektikçe, büyüleyicilikleri de taleple birlikte yeniden üretilmiş olması gereken bu mekânların belki de en önemli sorunu budur. İnsanlar tükettikleri ortamlarda mekanik denebilecek türdeki bu verimlilikten sıkılmak, vazgeçmek eğilimindedirler. İçine girdiğinizde dışarı çıkmanın zorlaştığı bu mekanlarda, kullanışsız mallar çoğaldıkça ve bu tek tip tüketim çılgınca devam ettikçe giderek artan akılcılığın karşısında büyüleyiciliğin tesisi önemli bir probleme dönüşmektedir (Ritzer, 2019: 33, 116). Yaşam merkezleri olarak alışveriş merkezleri de bu temel problemin üstesinden gelme amacı etrafında şekillenmişlerdir.

Günümüz yaşam merkezlerinin ortaya çıkışını iki boyutta incelemek mümkündür. Bunlardan ilki yükselen akılcılaştırılmanın yarattığı bir gereklilik olarak okunabilir. Bu durum Bauman'ın aktardığı "iatrojenik" hastalıklara fazlasıyla benzemektedir. Bauman "erişilebilir", "hakiki" ve "gerçekçi" arzulara nesnel sınırlar koyulabileceğine yönelik inancın tüketim toplumunun, tüketim endüstrisinin ve tüketim piyasasının ölüm çanları olduğunu vurgulamaktadır. Amaç tatminsizliğin kalıcılaştırılmasıdır ve en geçerli yol; "[...] tüketicilerin arzularını kuşatan evrene büyük bir heyecanla pompalandıktan sonra, çok geçmeden tüketim ürünlerini karalamak ve değersizleştirmektir. Fakat daha etkili olan diğer yol kendisini gözlerden hep uzak tutmaktadır; Her ihtiyacı/arzuyu/gereksinimi, yeni ihtiyaçlar/arzular/gereksinimler yaratacak şekilde tatmin etmek." (Bauman, 2018: 106-107). Geçmiște uygulanan tıbbi tedavilerin yol açtığı hastalıklar olarak tanımlanan "iatrojenik" kavramı burada uygun bir metafor sunar, yaşam merkezleri aracılığıyla yaşam tarzlarının tüketim sürecine dâhil edilmesinin arkasında yine tüketimin bir önceki evresinin sonuçları yatmaktadır. Akılcılaştırılan alışveriş merkezleri, büyüleyiciliğin tesisini gerekli kılmış, bu gereksinim yaşam merkezleri ile farklı bir boyuta taşınmıștır. Şüphesiz bu merkezleri de bir diğeri izleyecektir.

Diğer boyut ise tüketicilerin yaşam beklentileri ile yakından ilişkilidir. Bir önceki başlıkta incelediğimiz beğeni ve sermaye kavramları burada devreye girer. Ayrımda ekonomik ve kültürel sermayenin temel işlevi bu dönüşüm noktasında, yaşam beklentilerinin habitus ile olan ilişkisinde görülür. Belirli sermaye türlerinin belirli birikimlerinin taşıyıcıları olarak farklılaşan toplumsal sınıflara mensup bireyler, sınıf habituslarının onları yönlendirdiği biçimde sermayelerini değerlendirmeye yönelik bir yatkınlık geliştirirler (Bourdieu, 2015a: 265). Burada ayrım, tüketim ile iç içe geçmiş yeni bir sınıfsallık oluşturmuştur. Featherstone'un yeni küçük burjuvazi şeklinde tanımladığı bu sınıf, kültürel sermayeye devamlı yatırım yapar ve "hayat tarzları arayışındaki en çocuksu aristokratik niteliklerin (üslup, ayrım, zarafet) cazibesine kapılması açısından eski küçük burjuvaziden ve işçi sınıfından ayrılır". Yeni küçük burjuvazi, her zaman olduğundan fazlasını ister ve hayat karşısında sürekli öğrenmeye açık kalır, kendisini beğeni ve yaşam tarzları konusunda eğitir (Featherstone, 2013: 161-162), estetik yașam ve etik arasında bir bağ kurar, benliğin ve hayatın estetik olarak sürekli şekillendirmeye açı olduğunu kabul eder (Featherstone, 2013: 96). Bu iki boyutun birbirleriyle yakın ilişkide olup, yaşam merkezleri kavramıyla anılan mekânların gelişiminde ön ayak olduğunu düşünmekteyiz. 
$\mathrm{Bu}$ dönüşümde göze çarpan, akılcılaştırmanın iki önemli aracı "hesaplanabilirlik" ve "öngörülebilirliğin" yerini bıraktığı "yeni deneyimler" meselesidir. Hesaplanabilirlik sıklıkla sayılabilir, nicelleştirilebilir șeylere vurgu yapar ve çoğunlukla nitelikten feragat etmeyi beraberinde getirir. Ritzer, McDonalds, Burger King, KFC gibi firmaların menülerinde "büyük", "daha büyük", "mega mega büyük" gibi ifadelerin sıklıkla karşılaşılmasının bu bağlamda anlamlı olduğunu vurgular ve ekler; burada ilginç olan niteliğin bir kaygı olarak tüketicide de bulunmamasıdır. Akılcılaşmış sistemin tüketicisi genel olarak en yüksek kalitede ya da özel ürünler satın almadıklarını bilirler, önemli olan neye sahip olacağını bilmek, öngörebilmektir (Ritzer, 2019: 137-138). Ne var ki günümüz tüketicisi için bu tutum değişmektedir, tüketilen ürün/hizmet iyi olabilir fakat iyi olması büyülemek için yeterli görünmemektedir. Önemli olan özel olana ulaşabilmektir. Yaşam merkezlerini diğer örneklerinden ayıran faktörlerden biri de burada yatmaktadır. Bu merkezlerde daha yüksek ücretlerle, daha çeşitli menüleriyle "özel" mutfakların mekânlarıyla karşılaşmanız tesadüf değildir. Bu tür mekânların menülerinde "şefin sosu" (çoğunlukla içeriği paylaşılmaz), "homemade -ev yapımı-" (ev her zaman özel olanı çağrıştırır) ve bunun benzeri kelimelere rastlama ihtimaliniz daha yüksektir. $\mathrm{Bu}$ da büyülemenin bir yoludur; restoranın kapalı mutfağından çıkacak şefin sosu, fast-food mağazasının açık mutfağından çok daha mistik, özel bir deneyime işaret eder. Yaşam merkezleri büyük fast-food zincirlerini içermekle birlikte bunları mekânsal olarak ayırmışlardır. Görece daha uygun fiyatlı ve hesaplanabilir tüketimin alanı olan fast-food mekanları (çoğunlukla en üst katta yer alırlar) bu "özel" mutfaklardan açıkça ayrılırlar. Niteliğe vurgu yapan veya yerel üreticilerin yer aldığı restoran ya da yeme-içme alanlarından ayrı bir katta yer almakta ve bir üretim bandını andıracak şekilde yan yana sıralanmaktadırlar. Bu toplumsal anlamıyla ayrımın pekişmesinde önemli bir mekânsal rol oynar. Sınıf habitusunun bir sonucu olarak oluşan farklılaşma kültürel bir göstergeye dönüșmüș, bu dönüşüm fiziksel olarak somutlaşmıştır. Nerede yemek yediğiniz yaşam tarzınızın bir gösterisine dönüşür ve ayrımı yeniden üretir. Bunun yanında tüketici için alternatifler alışılageldik bir alışveriş merkezinin ötesindedir; restoranlar, barlar ve özellikle organik pazarlar ve yerel üretici etkinlikleri gibi mekân ve girişimler aracllğıyla ana akım tüketim pratiklerine alternatif bir tüketime imkân oluşturulur. Birçok alışveriş merkezinde ve yaşam merkezinde örneklerini görmenin mümkün olduğu "organik gıda" temalı etkinlikler de bu türden bir amaca hizmet eder. MaviBahçe Alışveriş ve Yaşam Merkezi'nin Ege'nin üreticilerinin "kendi elleriyle ürettikleri, temiz içerikli gerçek gıda" için "MaviBahçe Pazar Yeri"nde düzenlediği etkinliği bu örneklerden yalnızca biridir. Etkinlik kapsamında Tire, Foça ve Urla gibi Ege ilçelerinden üreticilerin ağırlandığı görülmektedir (MaviBahçe Etkinlikler, t.y.). Bu yolla kentli tüketici, "otantikliğin tüketimi" olarak yeni bir deneyimle tanışmaktadır. Bununla birlikte bu tercih paletine yaşam merkezinin güvenilir ve konforlu sınırları dâhilinde kavuştuğu da unutulmamalıdır (Zukin, 2008: 724).

Akılcılaştırma yalnızca gıda sektörüne ilişkin gerçekleşmez, fast-food mağazalarının birbirine benziyor ve tek tür bir deneyime işaret ediyor olması, tüketimin verimli, hesaplanabilir ve öngörülebilir olmasının beraberinde getirdiği bir dezavantajdır. Alışveriş merkezlerinde karşımıza çıkan kitapevleri de benzer bir örnek teşkil etmektedir, tek bir reçeteye uygun planlanmış mekân ve satış politikaları bu mağazaları da fast-food akılcılığına sürüklemektedir. Kendi içerisinde küçük bir alışveriş merkezini andıran bu mağazalar, birbirinden ilginç ve çeşitli ürünlerle dolu raflarıyla kitlesel tüketimin bir diğer manzarasını oluştururlar; tabii ki bu rafların en büyük ve en görünür olanı best-seller (en çok satılan) olan ya da olması beklenen ürünlere ayrılır. Şüphesiz bu entelektüel alışverişin rayından çıkmış bir örneğidir ve yaşam merkezleri bu noktada da diğer örneklerinden ayrılmaktadır. Yaşam merkezleri, çeşitli etkinliklerle kitap tüketicisini de büyülemenin yollarını arar; Akasya Kitap Festivali, İlber Ortaylı gibi ünlü yazarlarla gerçekleştirilen imza günleri, farklı konu ve konuşmacıların söyleşileri ve çeşitli etkinlikleri içeren takvimiyle bu anlamda verilebilecek örneklerden yalnızca bir tanesidir (Akasya Kitap Festivali, t.y.). Bu ve bunun gibi etkinlikler giderek tek tipleşen ve her şeyin aynı göründüğü hizmet anlayışının akılcılığını aşma girişimi olarak okunmalıdır. 
Gündelik hayatın tüm ihtiyaçlarını karşılama iddiasındaki merkezler, repertuvarlarına entelektüel deneyimleri de eklemektedirler. Bu merkezleri diğer örneklerinden ayıran bir diğer önemli nokta budur. Kültürel ve sanatsal etkinliklere önem verilen merkezlerde sıklıkla geniş bir yelpazede atölye çalışmaları gerçekleştirilmektedir. Tiyatro oyunları, konserler, sanat söyleşilerinin yanında, satrançtan yemek yapımına, tasarım, oyuncak, ahşap vb. çeşitli atölyelerle tüketicisine "farklı" bir alışveriş merkezi deneyimi sunma çabasındadırlar. Panora Alışveriş ve Yaşam Merkezi bünyesinde yer alan Actor Studio bu anlamda verilebilecek örneklerden biridir. Merkezde yaratıcı dramadan resim ve müzik sanatlarına kadar çeşitli alanlarda eğitim faaliyetleri gerçekleştirildiği belirtilmektedir (Panora Alışveriş ve Yaşam Merkezi, t. y.) Featherstone'u takip edersek bu tam da tüketicinin istediği șeydir; "Sürekli öğreniyor ve kendini zenginleștiriyor olma arzusu, her zaman yeni değerler ve sözcük dağarları peşinde koşma arzusu ve kimi postmodernistlerin savunduğu sanatçı ve entelektüelin kahraman olarak görüldüğü bitimsiz merak" bu yeni orta sınıfı betimlemektedir (Featherstone, 2013: 96-97). Özellikle söyleşiler, tartışma kulüpleri ve sıklıkla düzenlenen atölyelerle bu ayırt edici yaşam tarzı ve daha önceden üst sınıfların eriştiği ruhsal zenginlik göstergeleri pekiştirilir ve mutabakata varlan ortak bir söylence oluşturulur. $\mathrm{Bu}$ söylencenin oluşmasında ise Bourdieu'nün 'yeni entelektüeller' olarak nitelediği grup önemli bir işlevi yerine getirir. Medya, reklam, moda ve çeşitli terapi ve danışmanlık gibi meslek kollarında yer alan bu popüler kılavuzlar ve yaşam tarzı pratiklerinin üreticileri, ideolojiler üretip gündelik hayata dair pratik fikirler sunarken sanat ve düşünce dünyasından da yararlanırlar. Tüketici yeni simgesel malların kullanımında bu kültür uzmanlarına ve aracılarına ihtiyaç duymakta ve bu türden bir kimlik, sunum, görünüm, yaşam tarzı ve sonsuz yeni tecrübeler arayıșı karşısında büyülenmektedir (Featherstone, 2013: 48, 77, 91). Yaşam merkezleri Bourdieu'nün 'yeni entelektüelleri' için uzmanlıklarını kitleyle paylaşmaları noktasında önemli bir alan yaratırlar. Yaşam merkezleri de bu yolla büyülemenin bir diğer șekline sahne olur. Kanyon Alışveriş Merkezi'nde düzenlenen Fit Weekend etkinliği bu türden bir etkinlik için güzel bir örnek teşkil etmektedir; etkinlikte yogadan ruhsal hafiflemeye, annelikten yaşam koçluğuna geniş bir yelpazede söyleşiler düzenlendiği görülmektedir (Fit Weekend, t.y.).

Burada büyüleyici olan tercihlerin çekiciliğidir, nitekim oluşturulması hedeflenen yeni hayat tarzında kurallar değil, tercihler vardır. Tüketim imgeleri, alanları ve yeni orta sınıfın hayatı estetikleştirme çabası, gündelik hayatı idealize edilmiş deneyimlerin dünyasına dönüştürme iddiasındadır. Tüketim dünyası, yeninin peşinde koşan, modayı takip eden, maceradan hoşlanan, riske giren, sahip olduğu tek hayattan zevk alması ve bunun için çabalaması gerektiğini bilen kişilerin dünyasıdır. Bu kişiler yalnızca bedensel görünümleri ile değil, mobilyalarıyla, otomobilleriyle ve gerçekleştirdikleri etkinliklerle bir hayat projesine katılırlar (Featherstone, 2013: 155). Yaşam merkezleri de bu projeye önemli katkılarda bulunur; İzmir'de yılbaşını yapay kar gösterisi ile karşılayan tüketici (Habertürk, 2018), sevgililer gününe özel yemek atölyesine katılabilir (Kent Meydanı Avm, t.y.), ya da tavus kuşları, tavşanlar, köpek ve kedilerle iç içe natürel bir yaşamın kapılarını aralayıp, Kapalıçarşı'nın minyatür mimarisiyle donatılmış bedestende tarihi bir yolculuğa çıkabilir (Viaport Outlet Shopping, t.y.).

Tüm bu etkinlikler ele alındığında alışverişin ötesine geçen bir dünya ile karşılaşmaktayız ki "yaşam merkezi" iddiası bu açıdan anlamlı bir iddiaya dönüşmektedir. Artık bu merkezler yeme-içme ve eğlencenin ötesinde sosyalleşmenin, entelektüel faaliyetlerin, yazma, okuma ve öğrenmenin, kutlama veya tartışmanın ya da yalnızca keyifli bir yürüyüşün mekânına dönüşmektedir; kültür, sanat, müzik, ya da fast-food, alışveriş, eğlence, tüm bunlar aynı sınırların içerisinde birbirine karışmaktadır. Yaşamın merkezi bu mekânlara kaydıkça, bu mekânlar da "kent"leşmektedir.

\section{$4 \quad$ Kentin Yeni Hali: Simülasyon Olarak Yaşam Merkezleri}

1999 yılının Haziran ayında ABD Ohio'da açılan Easton Town Center isimli alışveriş merkezi, perakende satış sektöründe önemli bir konumda yer almasının yanında, bizlere alışveriş için örgütlenen bir mekânın ne kadar ötesine taşabileceğine dair çarpıcı bir örnek sergilemektedir. Küçük bir Amerika şehrini anımsatan merkezin resmi internet sitesindeki kuruluş amacı 
çalışmamızın konusu açısından ayrıca önem taşımaktadır; "Kentin çekiciliği nostaljik cazibeyle birleşecek ve güçlü bir mekân duygusu uyandıracak". Gerçekten de merkez önde gelen mağaza zincirlerinin yanında dünya mutfağının çeşitli örneklerinin sunulduğu restoranlara, sağlık tesislerinden eğlence tesislerine, konaklama için inşa edilen konutlardan çeşitli otellere, tren istasyonundan kent meydanları, parklar ve çeşitli rekreasyon alanlarına kadar devasa bir yapı oluşturmaktadır (Easton Town Center, t.y.). Bu, yaşam merkezlerini ayırt eden özelliklerin son ve nihai adımıdır denilebilir. Burada gerçekleșen tüketim, yașam tarzının işaret ettiği toplumsal bir ayrıma aracllık etmenin yanında, tüketimin mekânı kentin bir simülasyonuna dönüşür ve kent alışveriş merkezine, kentlilik ise tüketime indirgenip, iç içe geçirilir. Burada artık tüketim de bildiğimiz şekliyle tüketim olmaktan uzaktır; söz konusu olan kent, kentlilik, yaşam tarzı, sınıf, ayrım, tüketim vb. çeşitli göstergelerin bir oyunundan ibarettir.

Jean Baudrillard'ın tüketimi ele alış şekli bu türden bir ilişkinin analizinde açıklayıcı olacaktır. Düşünür için tüketim, basitçe bir statü taşıyıcısının ötesindedir. Tüketim; yalnızca nesnelerin işlevsel pratiği üzerinden gerçekleşen bir eylem ya da mülkiyet aracılığıyla edinilen bireysel ya da toplumsal işleve hizmet eden bir süreç de değildir. Tüketim, "iletişim ve değiş tokuş sistemi olarak durmadan verilip alınan ve yeniden yaratılan göstergeler kodu olarak" tanımlanır (Baudrillard, 2016a: 110-111). Simülasyon kavramı da bu noktada devreye girer; günlük yaşamın her alanında, gerçeğin nitelikleri ve öğeleri birleştirilerek yeni bir model imal edilir ve gerçeğin mevkiine, bu "simülasyon modelleri" aracılığılla üretilen bir "yeni-gerçek" konumlandırılır (Baudrillard, 2016a: 160).

Baudrillard simülasyonun tanımını; "Bir köken ya da bir gerçeklikten yoksun gerçeğin modeller aracılığıyla türetilmesine hipergerçek yani simülasyon denilmektedir." ifadeleriyle sunmaktadır (Baudrillard, 2016b: 13). Gerçek olan ve gerçeğin temsili arasındaki kesin ayrımın ortadan kalktığı bu süreçte söz konusu olan bir parodi ya da basit bir taklidin ötesinde, göstergelerin sürekli yeniden üretildiği ve aslının yerini aldığı bir simülasyon evrenidir. Burada önemle beliren nokta, "simüle etmek" ile "-mış gibi yapmak" eylemleri arasında yatan farkta kendisini göstermektedir. Hasta bir bireyin davranışları üzerinden bu farkı örneklendiren Baudrillard, hastaymış gibi yapan kişinin yatağa uzanarak bizi hasta olduğuna inandırmaya çalışacağını, fakat bir hastalığı simüle eden kişinin kendinde bu hastalığa ait semptomların göstereceğini belirtir. Hasta "simülasyonu" semptomlar üreterek gerçekliğin yerini almaktadır (Baudrillard, 2016b: 14-16). Simülakr kavramı da bu noktada konumlanır; göndereninden daha gerçek, gerçeğin yerini alan ve onu buharlaştıran, "Bir gerçeklik olarak algllanmak isteyen görünüm" olarak simülakr, simülasyon evreninin temel yapıtaşıdır (Baudrillard, 2016b: 7).

Yaşam merkezleri bir simülasyon alanıdır ve burada söz konusu olan artık yalnızca bir tüketim deneyimi değil, kentlilik simülakrının bir örneği şeklindedir. Bu merkezlerin neredeyse hepsinin açık ya da yarı açık yapılar olduğu unutulmamalıdır. Forum Bornova, Forum Kapadokya, Forum İstanbul vb. örneklerde görebileceğimiz şekliyle bu mekânlar küçük göletler ve köprülerin yer verildiği sokaklardan oluşmakta, kendi isimleri olan bu sokakların kesiştiği noktalar küçük meydanlara çıkmaktadır. Ege Bölgesinin ve İzmir'in ilk açı hava alışveriş merkezi olan Forum Bornova; resmi internet sitesinde geçen ifade ile "Ege mimarisinin eşsiz özelliklerini bir Akdeniz kasabası ölçeğinde bir araya getiren", iki ayrı bulvar, bunları birbirine bağlayan meydanlar ve dört ayrı sokaktan oluşmakta, İzmir'in doğal dokusuyla uyum içerisinde bir yaşam merkezi sunma iddiasındadır (Forum Bornova, t.y.). Benzer bir diğer örnek Kent Meydanı AVM'nin resmi internet sitesinde yer verilen ifadelerde gözlemlenebilir. Gerçekleştirdiği açıkhava etkinlikler, konser ve projelerle Bursa'nın kültürel merkezi olma iddiası ile merkez hareketli ve canlı bir yaşam merkezi olarak tanımlanmaktadır (Kent Meydanı AVM, t.y.). Mavibahçe Alışveriş ve Yaşam Merkezi, bu konuda bir diğer örneği teşkil etmektedir. "İzmirli bir kent meydanı olarak hayal edilerek" tasarlanan yapının mimarı için Ege mimarisinin en öne çıkan yanı ise mutlu, huzurlu ve keyifli olmasıdır; "Bu yoldan çıkarak, MaviBahçe'nin mimarisinde canlı renkler, malzemeler, teraslar, sular, gölgeler, cumbalar, balkonlar, beyaz pergolalar, ferforje detayları, peyzajı, saat kulesi gibi 
İzmire has mimari detaylar kullanılarak İzmirli bir "keyif ortamı" yaratıldı." (MaviBahçe, t.y.). Örneklerin çoğaltılabileceği ve simülasyonun basitçe bir -mış gibi yapmak olmadığını unutmamamız gerekmektedir. Tüketimin belirleyiciliği artık anlam dünyamızla iç içedir, Mavibahçe ya da bir diğer örnek, tüm bu merkezler yalnızca kentin bir parçası değil, birçok yönüyle kentin bilgisini kendinde taşıyan bir modele dönüşmektedirler.

Baudrillard için kentler tüketim mantığının bir sonucu olarak anlamını yitiren ve simülasyon evreni ile yeniden üretilmesi çabalanan bir modelden ibarettir; "[...] yeni kentler, hipermarket ya da shopping center'ların uydularına dönüşmüşlerdir. İnsanlar bu uydulara programlanmış bir toplu taşma ağıyla ulaşmaktadırlar. Bunlar kentten çok bir banliyöye benzemektedirler." Düşünür çoktandır kent olma özelliğini yitirip dağılan kentin, kent dışına taşınarak hipergerçek bir model, artık kentle hiçbir ilişkisi kalmamış sentetik bir yerleşim bölgesi çekirdeği haline dönüştüğünü savunur (Baudrillard, 2016b: 111-112). Simülasyon evreni ile birlikte anlamını ve işlevini yitirmiş her kavram yeniden keşfedilmektedir; "Yaşamla ilgili her şeye, örneğin yitirilmiş yetenekler, yitirilmiş vücutlar, yitirilmiş toplumsallık ya da eski tadını yitirmiş yiyeceklere kısaca her alanda her şeye eski işlevi yeniden kazandırılmaya çalışılmaktadır." (Baudrillard, 2016b: 31).

Yaşam merkezlerinde tüm bu olgular birbirine geçmektedir. Şüphesiz tüm bu yaşam tarzl, tüketim yoluyla var olma çabası, kent ve kentlilik gibi konuların temelinde yatan bir diğer şey ise kimlik meselesidir. Baudrillard'ı takip edersek görece yeni bir kavram olarak bireyselleşmenin yarattığ birey olma özgürlügü, tüketim eylemlerinin odağında ağır bir sorumluluğa dönüşmüştür. Düşünür için kendimizi tüketmek pahasına bu kimlik "oyununu" sürdürmekte, kendimizi temsil ettiğini düşündüğümüz bir hayaleti yaşatmaya çabalamaktayızdır (Baudrillard, 2015: 52-55). Günümüzde kimlik, tıpkı tüketim malları gibi sonsuza dek var olmamalı, değişime açık ve esnek olmalı, gerektiğinde yok olmalıdır. Bauman’a göre de kimlik inşasında yaşanan belirsizlikler "gerçek ve taklit", "normal ile anormal", "biz ve onlar" arasındaki sınırları bulanıklaştırır (Bauman, 2000: 3241). Bu yüzden düşünür bu süreci alışveriş merkezlerinden ayrı ele almaz: "Satın alınabilir, uzun süre dayanmayan, kolaylıkla sökülebilen, tamamıla değiştirilebilir olan sembollerden gevşekçe oluşturulmuş ve genellikle mağazalardan elde edilebilen 'toptan kimlikler', çağdaş yaşamın meydan okumalarına karşı koymak isteyen birinin kesin olarak ihtiyacı olan şey"dir (Bauman, 1999: 47). Giddens için de yaşam tarzları özünde kim olduğumuz sorusu ile ilişkilidir. Hayat tarzları rutinleşmiş pratiklerdir ve bireysel kimliğin özüyle, onun inşası ve yeniden inşasıyla bağlantılıdır; "Bir kişinin her gün aldığı küçük kararlar -ne giymesi ne yemesi, işte nasıl davranması, akşam kiminle buluşması gerektiğiyle ilişkili kararlar- bu tür rutinlere katkıda bulunur (Giddens, 2014: 111). Yaşam merkezleri hedeflerine bu rutinleşmiş pratikleri almaktadırlar, kentlilik deneyimi de burada başlar; söz konusu olan yalnızca bir satın alma eylemi veya eğlenceye ayrılan zaman değildir. Kent yaşamına özgü kültürel ayrımın bir mekanına dönüşen bu merkezler mimarisi ile yaşadığınız şehir ile, etkinlikleri ile kültürel kimliğiniz ile bağ kurmanızı amaçlar. Fakat daha da önemlisi tüm bu yelpazenin kentlilik üzerinden sunuluyor olmasıdır. Bu süreç -mış gibi yapmanın ötesine geçer ve kentlilikten ne anladığımız ile yakından ilişkili bir hal alır; kentlilik yalnızca bir tüketim deneyimi değil, bir simülakra dönüşmektedir.

\section{Sonuç}

Gün geçtikte göstergeler tarafından kuşatılmaktayız, içeriği üretmek yerine satın alabileceğimiz göstergelere başvurmak çok daha kolay ve gittikçe işlevi de artıyor. Yaşam merkezlerinin çekiciliği de burada yatmakta, birbirinden çeşitli göstergeleri bünyelerinde barındıran, tüketimin yalnızca ürün alışverişi olarak değil, bütünleşmiş bir göstergeler sistemi, yaşam tarzı, bir kimlik ögesine dönüștüğü, yaşamın ve kentin kompakt, yeni halini sunmaktalar. Bu biraz da Baudrillard'ın Melanezyalı yerlilere ilişkin sunduğu örneği hatırlatıyor. Gökyüzünden geçen uçaklara hayran kalan yerliler, dallar ve sarmaşıklarla, geceleri özenle aydınlatacakları bir toprak parçasının sınırlarını çizerler ve bir havaalanı simülakrı inşa edip, sabırla gerçek uçakların oraya inmesini beklerler. Buradan tüketim toplumu üzerine bir ders çıkarmanın mümkün olduğunu söyleyen Baudrillard ekler; "Tüketim kazazedesi de simülakr nesnelerden ve mutluluğun karakteristik göstergelerinden 
olușan tüm bir aygıtı işlerliğe sokar ve ardından (bir ahlakçının umutsuzca diyeceği tarzda) mutluluğun konmasını bekler." (Baudrillard, 2016a: 23). Yaşam merkezleri ile artık kültür, tüketimin alanındadır, kültürel ayrımın göstergesi de neyi, nasıl tükettiğimize dönüşmektedir. Tüketici takip etmesi giderek zorlaşan bu dinamik göstergeler sisteminde kimliğini, kentliliğini, kültürel bağlamda sınıfsallığını -Bourdieu'cü anlamda ayrımı da- bu mekanlarda aramaktadır.

Burada çarpıcı olan, kültür ve kültürel ayrıma işaret eden yaşam tarzı kavramlarının doğasının, tüketimin dinamizmine uygun olmamasıdır. Kültürel faaliyetlerimiz, beğeni yargımız, yaşam tarzımızı oluşturan davranış kodlarımız habitusumuzla yakından ilişkilidir ki habitus bireyin doğumu ile başlar, önce aile, sonra eğitim sistemi ve yaşantısı boyunca gelişen bir yatkınlıklar sistemi olarak çalışır. Dolayısıyla kültür ve yaşam tarzı, hızla değişen dinamik bir moda dünyasını takiben değiştirilebilecek ya da sürdürülebilecek kavramlar değillerdir. Örneğin modayı takiben bir kıyafetin satın alınıp kullanılması ile, modayı takiben bir yaşam tarzı geleneğinin sürdürülmesi veya kültürel etkinliklerin takibi aynı şey değildir. Söz konusu yaşam tarzı ve kültür olduğu noktada tüketim, gerçekten de bir yaşam şekline dönüşmeye başlar, bu yeni yaşamın merkezi de kaçınılmaz olarak alışveriş merkezlerinin yeni formu, farklılaştığını düşündüğümüz yönleriyle ele aldığımız yaşam merkezleri olacaktır.

Tüketim bireyselliğin sonu gelmeyecek bir arayışa dönüşmesiyle günümüz dünyasına derinden etki etmiştir; anlaşılan artık ne tükettiğimiz konusu değil, nerede ve ne şekilde tükettiğimiz konusu giderek önem kazanmakta ve tüketim başlı başına bir yaşam tarzı olarak öne çıkmaktadır. Buradan hareketle tüketim, kültürel ve sanatsal faaliyetlerden sabah kahvaltımıza, sosyal etkileşimin her türüne bulaşıp, yaşam merkezleri gibi alışveriş merkezlerinde birer deneyime dönüşmektedir. $\mathrm{Bu}$ deneyimin büyüleyiciliği bir yana, tüm bu repertuarın akılcı bir paket dâhinde sunuluyor olması da ayrı bir konudur; aracınızı park etmek bir sorun olmaktan çıkar, merkezin güvenliği istenmeyenleri dışarıda tutar ve giderek vakti azalan tüketiciye sıkıştııılmış bir kent deneyimi vaat eder. Buradan bakıldığında yaşam merkezlerinde hedeflenen șey tüketicinin gündelik, haftalık ya da aylık rutinleridir; yalnızca kıyafet, oyuncak ya da bakım ürünü alışverişi sizi bu mekâhara çekmez (ya da her zaman çekmeyecektir), bununla birlikte, kentli zevkinize uygun sanatsal faaliyetlerden, kültürel etkinliklere, geniş menüsüyle deneyiminize renk katacak restoranlardan, gündelik molanıza layık kahveleriyle çeşitli mekâharına kadar her şey düşünülmüştür, soluklanmak isterseniz göl kenarında bir bank işinizi görecektir. Alş̧veriş bu deneyimin merkezinde değil, bu deneyime bütünleştirilmiştir, artık merkeze alınan yaşantınızdır.

Hakem Değerlendirmesi: Dış bağımsız.

Çıkar Çatışması: Yazarlar çıkar çatışması bildirmemiştir.

Finansal Destek: Yazarlar bu çalışma için finansal destek almadığını beyan etmiştir.

Peer-review: Externally peer-reviewed.

Conflict of Interest: The authors declare no potential conflicts of interest with respect to the research, authorship, and/or publication of this article.

Grant Support: The authors received no financial support for the research, authorship, and/ or publication of this article.

\section{Kaynakça/ References}

Adanır, O. (2016). Baudrillard. İstanbul: Say Yayınları.

Akasya Kitap Festivali. (t.y.). 17-18-19 Ocak tarihinde Akasya'da buluşalım! 19 Mart 2021 tarihinde https://ak-asya.com.tr/akasya-kitap-festivali-programi/ adresinden erişildi. 
Batı, U. (2009). Tüketimin akılcılaşması, büyülemesi ve yeniden büyülemesinin İkea Süper Mağazası üzerinden görünümü. İstanbul Üniversitesi İletişsim Fakültesi Dergisi, 37, 20-48.

Baudrıllard, J. (2015). Şeytana satılan ruh: Ya da kötülüğün egemenliği (O. Adanır, Çev.). Ankara: Doğu Batı Yayınları.

Baudrıllard, J. (2016a). Tüketim toplumu: Söylenceleri ve yapıları (H. Deliceçaylı ve F. Keskin, Çev.). İstanbul: Ayrıntı Yayınları.

Baudrıllard, J. (2016b). Simülakrlar ve simülasyon (O. Adanır, Çev.). Ankara: Doğu Batı Yayınları.

Bauman, Z. (1999). Çalışma, tüketicilik ve yeni yoksullar (Ü. Öktem, Çev.). İstanbul: Sarmal Yayınevi.

Bauman, Z. (2000). Postmodernlik ve hoşnutsuzlukları (ì. Türkmen, Çev.). İstanbul: Ayrıntı Yayınları.

Bauman, Z. (2018). Akışkan hayat (A. E. Pilgir, Çev.). İstanbul: Ayrıntı Yayınları.

Bloch, P. H., Ridgway, N. M. ve Dawson, S. A. (1994). The shopping mall as consumer habitat. Journal of retailing, 70(1), 23-42.

Bourdieu, P. (2007). Outline of a theory of practice. Cambridge, UK: Cambridge University Press.

Bourdieu, P. (2015a). Ayrım: Beğeni yargısının toplumsal eleștirisi (D. Fırat ve G. Berkkurt, Çev.). Ankara: Heretik Yayıncllı.

Bourdieu, P. (2015b). Pratik nedenler (H. Uğur Tanrı̈ver, Çev.). İstanbul: Hil Yayın.

Çalışlar, İ. (2019). Takastan paraya, agoradan çarşıya, bedestenden AVM'ye alışveriş. İstanbul: Alışveriş Merkezleri ve Yatırımcıları Derneği.

Easton Town Center. (t.y.). The Easton story. 19 Mart 2021 tarihinde https://eastontowncenter.com/guest-information/the-easton-story adresinden erişildi.

Featherstone, M. (2013). Postmodernizm ve tüketim kültürü (M. Küçük, Çev.). İstanbul: Ayrıntı Yayınları.

Fit Weekend. (t.y.). 19.03.2021 tarihinde http://www.fit-weekend.com/ adresinden erişildi.

Forum Bornova. (t.y.). Hakkımızda. 19 Mart 2021 tarihinde https://forumbornova.com/hakkinda adresinden erişildi.

Giddens, A. (2014). Modernite ve bireysel kimlik: Geç modern çağda benlik ve toplum (Ü. Tatlıcan, Çev.). Ankara: Say Yayınları.

Habertürk. (2018). Yeni yıla MaviBahçe'de kar yağıșı ile 'merhaba' deyin. 19 Mart 2021 tarihinde https://www.haberturk.com/izmir-haberleri/65724424-yeni-yila-mavibahcede-kar-yagisi-ilemerhaba-deyin adresinden erişildi.

Kent Meydanı Avm. (t.y.). Kent Meydanı Avm'de lezzetli sevgililer günü kutlaması! 15 Temmuz 2021 tarihinde https://kentmeydani.com/kent-meydani-avmde-lezzetli-sevgililer-gunu-kutlamasi/ adresinden erişildi.

Kent Meydanı AVM. (t.y.). Hakkımızda. 15 Temmuz 2021 tarihinde https://kentmeydani.com/hakkimizda/ adresinden erişildi.

MaviBahçe Etkinlikler. (t.y.). Etkinlikler. 19 Mart 2021 tarihinde https://www.mavibahce.com.tr/etkinlikler?page=1 adresinden erişildi.

MaviBahçe. (t.y.). MaviBahçe Alışveriş ve Yaşam Merkezi. 19 Mart 2021 tarihinde https://www.mavibahce.com.tr/hakkimizda adresinden erişildi.

Panora Alışveriş ve Yaşam Merkezi. (t.y.). ActPor Studio. 15 Temmuz 2021 tarihinde https://www.panora.com.tr/culture-art-sport/actor-studio adresinden erişildi. 
Ritzer, G. (2019). Büyüsü bozulmuş dünyayı büyülemek: Tüketim katedrallerindeki süreklilik ve değişim (F. Payzın, Çev.). İstanbul: Ayrıntı Yayınları.

Ritzer, G., Stepnisky, J. (2014). Sosyoloji kuramları (H. Hülür, Çev.). Ankara: De Ki Basım Yayın.

Simmel, G. (2021). Moda. P. Kivisto, (Ed.). (A. G. Baran, A. Gelmez ve S. T. Afşar, Çev. Ed.). Sosyal teori: Kökler ve dallar içinde (ss. 197-204). İzmir: Islık Yayınları.

Simmel, G. (2021). Metropol ve zihinsel hayat. Kivisto, P. (Ed.). (A. G. Baran, A. Gelmez ve S. T. Afşar, Çev. Ed.). Sosyal teori: Kökler ve dallar içinde (ss. 215-226). İzmir: Islık Yayınları.

Swartz, D. (2015). Kültür ve iktidar: Pierre Bourdieu'nün sosyolojisi (E. Gen, Çev.). İstanbul: İletişim Yayınlarl.

Viaport Outlet Shopping. (t.y.). Viaport Outlet Shopping hakkımızda. 19 Mart 2021 tarihinde http://viaport.com.tr/tr/kurumsal adresinden erişildi.

Zukin, S. (2008). Consuming authenticity: From outposts of difference to means of exclusion. Cultural studies, 22(5), 724-748. 